\title{
Want it, Rent it: Exploring Attributes Leading to Conversion for Online Furniture Rental Platforms
}

\author{
Anuj Pal Kapoor ${ }^{1}$ and Madhu $\mathrm{Vij}^{2}$ \\ ${ }^{1}$ Indian Institute of Technology (IIT), School of Management and Entrepreneurship, Jodhpur, India, \\ anujkapoor@iitj.ac.in \\ 2 University of Delhi, Faculty of Management Studies, Delhi, India, drmadhuvij@fms.edu \\ Received 15 December 2019; received in revised form 4 June 2020; accepted 10 August 2020
}

\begin{abstract}
Online furniture rental platforms are expanding choice and convenience, allowing customers to rent from a wide array of providers with the click of a button or tap of a finger. The business of online furniture rental is undergoing rapid change as new online platforms race to capture markets and customers across most of the metropolitan cities in India. The paper aims to investigate attributes for online furniture rental platforms by proposing and empirically testing platform attributes-conversion model, examine how platform characteristics influence the renting decision of a consumer and how it subsequently lead to conversion. A mix method design was adopted for the study and a pilot study comprising of 341 respondents was carried out. The study focuses on six key attributes - occupational mobility, psychological ownership, complementary services, social gratification, perceived value, and customization, while identifying the most important attributes for renting furniture online.
\end{abstract}

Keywords: Online fashion renting, Access-based Consumption, Sharing economy, Collaborative consumption, Online furniture renting platforms 


\section{Introduction}

In recent years, the collaborative economy, often described as the sharing economy or access based consumption has achieved phenomenal success and influenced consumption patterns of digital savvy consumers [51], [61], [84]. The sharing economy has gained momentum in different contexts such as car renting, accommodation, music and clothing [51], [63], [83], [84]. In the last two years starting 2018, the concept of collaborative economy has emerged as an upcoming trend in the online fashion rental especially online furniture rental platforms (OFRPs) [1], [51], [94]. The online furniture rental industry has seen an impressive growth in the last two years and has become more popular than in-store shopping owing to affordable smartphones, multiple online purchase platforms and costeffective availability of internet or data [95], in turn leading to variety of products, availability of products, spatial and temporal convenience. As a result, the online renting market is gaining increasing traction [2], [9], [39], [97].

Globally, second hand online shopping, in particular, online renting has become the fastest growing segment [76] The second hand goods market is presently valued at $\$ 150$ billion in 2017 [88], [94] and the market is expected to be a $\$ 700$ billion market by 2022 [94], with fashion including apparel and footwear leading the way, followed by furniture and home decor. As per report [76], the online rental market is supposed to be a $\$ 335$ billion market by 2025. In India alone, the online rental market currently stand at around \$28 billion [76], whereas the online furniture rental market, including furniture, home décor and appliances is estimated to be a $\$ 2$ billion market. The rise of rental services platforms have led to a change in the Indian mindset and opened up to the idea of renting what customers need. Consumers have become more capricious and less loyal [26]. Online renting not only provides customers access to variety and aspirational designs but also value for money by renting furniture based on usage. As a result, an increasing number of startups have forayed into the online furniture rentals (Table 1).

The consumers have turned towards online renting for multiple reasons such as convenience, economic benefit, social status and personalized experience [70]. As a result, consumer wants to explore ready-to-live experiences provided by companies [48] and subsequently enhance their experiences [22], which has led to the development of alternative modes of acquisition and consumption based on collaboration and sharing between consumers [1], [21], [64], [85].

The performance of online rental platforms has drawn attention of academia as well as policymakers [51], however, studies on online renting are limited [11], [30], [52], [70], [77], [78]. In addition, related work has so far focused more on product-service systems [14], and does not involve any transfer of ownership [8], [9], [42], [61], but seemingly very few researches have focused on collaborative online platforms dedicated to second-hand sales [40], [53], [82]. For instance, (name of the author?) [82] studied in general the influence of second hand products on consumers. (Name of the author/s) [1] studied the impact of main characteristics of such platforms on satisfaction and behavioral intentions. Whereas [53], [79] focused on influence of variables such as trust in online-second hand markets. Despite the potential of the online rental market, little is known pertaining to consumer's perception of online furniture renting and the factors that affect consumers' intentions to rent fashion item online [51]. There is a pressing need to uncover the motivations of online renting, despite the popularity and revenue of online rental platforms. Research dealing with online furniture rental is still in its infancy [18]. Therefore, we aim to differentiate our research from prior work, by moving beyond drivers of initial acceptance. Consequently these variables have not been explored in the context of online renting, which forms the premise for proposed hypothesis in our study. Our aim is to instead explore consumers' online furniture renting behaviour as well as analyze the association between multiple attributes and final conversion (i.e., renting furniture). To bridge this gap, the objectives of this study are twofold. (1) To examine which of the platform attributes, consumer's attitudes and social norms influence the perception of consumers towards online furniture rental (2) To assess the impact of online furniture rental on the customer's experience in terms of actual conversion ,i.e., using web platforms (mobile app or website).

This paper addresses such shortcomings and examines the platform attributes and individual characteristics of consumers in order to examine the empirical association between individual characteristics, platform attributes and online furniture renting. This study is different from the existing literature as it combines online renting and the behavioral intentions in the new online furniture rental environment. This paper offers two substantive contributions. Firstly, by linking context specific attributes with actual conversión, i.e., renting through specific portals, this study provides quantified evidence that shows how attributes pertaining to online furniture rental impact customers' renting decisions. Secondly, using the concept of customer specific attributes, the study discusses how the mechanisms of online furniture rental portals could lead to an increase in online renting.. By applying these concepts to online portals or web based platforms such as mobile apps or websites, this study expands our understanding of how the use of interactive technology influences purchase behavior and in turn renting. Keeping in mind the self-reported measures of web based platforms [12], [54] and purchase intentions [98], our study adds to the collaborative economy literature, especially online renting, by incorporating behavioral measures of consumers towards using web based platforms. 
Table 1: Online furniture rental providers in India

\begin{tabular}{|l|l|l|l|l|l|}
\hline $\begin{array}{l}\text { Online Furniture } \\
\text { Rental } \\
\text { Providers }\end{array}$ & Model & $\begin{array}{l}\text { Launch } \\
\text { Year }\end{array}$ & Headquarters & Customer Base $^{*}$ & Funding $^{*}$ \\
\hline Furlenco & Rental Subscription Model & 2012 & Bangalore & 48000 & \$36 Million \\
\hline RentoMojo & Rental Subscription Model & 2012 & Bangalore & 25000 & \$27 Million \\
\hline City Furnish & Rental Subscription Model & 2015 & Gurgaon & 4500 & \$ Million \\
\hline Fabrento & Rental Subscription Model & 2016 & Delhi NCR & 1100 & Not Available \\
\hline GrabOnRent & Rental Subscription Model & 2015 & Bangalore & 35000 & \$ Million \\
\hline Fairent & Rental Subscription Model & 2012 & Delhi NCR & Not Available & Self \\
\hline Rentickle & Rental Subscription Model & 2015 & Delhi NCR & 10,000 & \$ 4.3 Million \\
\hline Voko & Rental Subscription Model & 2016 & Delhi NCR & Not Available & \$1.5 Million \\
\hline Guarented & Rental Subscription Model & 2015 & Bangalore & Not Available & \$5 Million \\
\hline & & & & & \\
\hline
\end{tabular}

The main goal is to help organizations in the online furniture market to better understand the issues related to these platforms and give recommendations about the type of strategy to adopt in order to address the requirements of the upcoming new market. To explore the role of online portals or web based platforms in consumer engagement, the current study developed and empirically tested a model to examine how customer specific and web based platform attributes influence the purchase decision of a consumer and subsequently lead to renting. The study focuses on six key attributes - perceived value, customization, social gratification, psychological ownership, occupational mobility and complementary services. Five of the constructs, i.e., perceived value, customization, social gratification, psychological ownership and occupational mobility have been adapted from previous studies whereas the sixth construct, complementary services is a result of the pre study conducted.

It was found that occupational mobility had the highest influence on conversión, i.e., rental of furniture through web based portals. Occupational mobility refers to movement of individuals from one geographic location to another due to change in their occupation. In other words, relocation to other cities for a better career prospect. People are hopping jobs in search of larger ownership and learning opportunities [59]. They are looking for different options to avoid troubles of shifting or reselling their existing furniture whenever they make a move. As a result, more and more people have started renting furniture online, to avoid the hassles of relocation. In addition to occupational mobility, complementary services such as free assembly, installation and de-installation was found to have the second highest influence on renting furniture online. Social gratification, i.e., acceptability among one's social circle and being regarded as a reference point due to owning latest designs and fashionable furniture, which otherwise would be beyond one's budget had the third highest influence on online renting. Followed by social gratification, perceived value, i.e., derived value in terms of price, convenience or savings, etc., in renting vs purchase, was found to be the next most important factor influencing online renting. Customization, i.e., ability for a user to customize a particular furniture as per choice was also found to have a positive influence on renting furniture online. However, psychological ownership was found to have a negative association with online renting of furniture.

The remaining part of this research paper is organized as follows: Section 2 contains the conceptual framework as well as theoretical explanation of the hypotheses considering current research findings. The employed research methodology used to explore second-hand purchases are explained in Section 3, and the results of the study are presented and discussed in Section 4. Section 5 discusses the findings and implications of the study. Section 6 concludes the document.

\section{Literature Review and Hypothesis Development}

In this section we describe the theoretical contributions in the field of online rental platform to highlight the gaps in the literature. Also, we present the main concepts and expected links behind the suggested hypotheses to be tested in the research model.

\subsection{Conversion Rate}

Conversion has been defined by various researchers in different capacities. Taylor \& Levin [93] defines conversion as an acceptance towards $\mathrm{m}$-commerce i.e., if an individual has used a particular platform such as mobile app or website, then it is defined as a conversion. On the other hand, [65] [67] describes conversion as a purchase i.e., when an individual actually makes a purchase through a platform, it is a true conversion. We have adopted the convention of Newman and defined conversion as, placing an order through either a mobile app or website interface, making a payment and renting a particular product online.

In our study, when a customer places an order through the online furniture rental company's website or mobile and have rented a particular product for atleast a month is considered as a conversion. In case a customer scans through the menu options and have not made any online purchase on the website of the online furniture provider, it is not considered as a conversion. Few empirical studies, which have been carried out based on mobile app attributes in 
the fields of information system and e-commerce support that attributes of a mobile app are salient stimuli that influence users' internal reactions and result in buying intention or actual purchase [6], [19], [20], [23], [34], [44], [54], [62], [65], [73], [81], [96]. Analogous to a commercial mobile app, an online furniture rental company is a multiattribute software product in which a combination of product and service attributes may influence users' experience that in turn affects their engagement behavior and final purchase.

\subsection{Psychological Ownership}

Psychological ownership is defined as a state where an individual feels as though the target of ownership or a piece of that target is "theirs" [74]. People with strong psychological ownership typically feel liable for their possessions [51]. In other words, people take great pride in owning a product and develop feeling of attachment whereas renting is more transactional and may only provide instrumental utility [8], [71]. Consequently, people with high psychological ownership would be more likely to value the possession of products more strongly than people with low psychological ownership [51]. For consumers who display strong ownership of products and services, the practice of renting might seem inconvenient and may cause them to renting a product as inferior to conventional fashion purchasing [13]. Therefore, the following hypothesis was formed:

\section{H1: Psychological ownership has the highest influence on the conversion rate of online furniture rental service}

\subsection{Perceived Value}

Perceived value is the tradeoff between 'what I get for what I give' [100]. A study by name?? [27], rephrased this as the tradeoff between benefits and sacrifices, emphasizing that there is no net perceived value in case the price is too high. It was found by name $i$ ? [60] that customers receive value for money when value derived out of a purchase is greater than the cost associated. Perceived value has multiple dimensions such as features and quality benefits, and sacrifices, such as temporal and spatial effort [91]. Prior literature related to perceived value has focused on the cognitive trade-off between perceived benefits and monetary cost for using them [99]. For example, when deciding to use mobile services, convenience is the benefit, and the monetary outlay is the sacrifice. Where price is relevant, price may influence the perception of value [86]. For example, when purchasing an item, the benefits of quality and comfort would outweigh the price to be paid. A classic example is of online food delivery. The consumer pays a premium amount for delivery of food at their doorsteps [43]. However, there are contexts where price may not be relevant [86]. Renting a car or renting a house is way more economical as compared to owning one. Under such cases, the value derived in terms of renting a particular product is way higher than the price paid for it [3], [4], [27], [99]. In the context of online renting, where the costs of renting are minimal, perceived value in renting furniture is way higher as compared to owning one. Therefore, the following hypothesis was formed:

\section{H2: Perceived value has the highest influence on the conversion rate of online furniture rental service}

\subsection{Social Gratification}

People have displayed their possessions and wealth as signs of material success and a barometer of personal achievement. But the idea of possessing wealth has shifted to displaying buying and borrowing power in the age of electronic transactions. Neuroscience provides evidence that money and social status are processed in the same brain region (the striatum) and people tend to define social standing by weighing their expenses and wealth. As far as online furniture renting is concerned, people rent furniture which is stylish and comes across as expensive [65]. Because it can signal money in the bank, we hypothesize that renting online furniture is associated with higher social status. In addition, social gratification is also referred to as the feeling which one enjoys, when an individual has higher social acceptability among friends, family or peer group. It is a pleasure one derives, when an individual is considered as a reference point for helping others in making decisions (Pre Study). With respect to online furniture rental, the type of furniture that is rented, for instance, all wood furniture vs medium-density fiberboard (MDF); and the aesthetic sense in choosing particular furniture represents one's personality. Individuals with better aesthetic sense by virtue of one's furniture are argued to have higher social acceptability within the peer group, for any advice pertaining to shopping online and not just furniture. Therefore, the following hypothesis was formed:

\section{H3: Social gratification has the highest influence on the conversion rate of online furniture rental service}

\subsection{Customization}

Customization may be viewed as a degree to which the company's offer is well adapted to meet heterogeneous customer needs [5]. Liao, Li, and Xu [56] defined customization in online commerce as the use of mobile technologies and of user, context, and content information to provide personalized products/services so as to meet the specific needs of the individuals. Choi, Seol, Lee, Cho, and Park [45] reported customization as one of the two common critical factors to both m-commerce and e-commerce. The advantages of customized offer and personalized content may attract and keep the customers loyal. In the context of online furniture rental, customization refers to searching products as per need and making changes with the product, to align to one's 
requirement. For example, renting a cupboard, whose color matches with the color combination of the room. Site 2 , which is an Indian startup for renting furniture, customers have the option to customize their furniture, to suit their current and dynamic requirements. One can choose from a variety of colors and shades, to match the interiors of one's bedroom or drawing room. Lai and Wang [49] reported that customization was an important predictor of quality in the context of e-commerce as well as m-commerce. Therefore, we propose the following hypothesis:

\section{H4: Customization has the highest influence on the conversion rate of online furniture rental service}

\subsection{Occupational Mobility}

Occupational mobility is defined as the process of changing profession [80]. It refers to changes in individual occupational status [102]. As per Zubieta and Lawson [102], career progression is a driver of occupational mobility. Changes within the professional career, for example, promotion from one level to another are usually associated with location. Specifically in India, the overall job landscape in the country is evolving rapidly [25]. An individual look out for a job change in every 2 years [61] and are increasingly becoming location agnostic. Changing their base location for career progression has become a norm [61]. Since, individuals are not sure about their location, individual prefer to stay in rented accommodations. Since accommodation is on a rental basis, they also prefer not to invest in assets such as car or furniture. Rather they prefer to rent. Investing in furniture is not considered to be a viable option and individuals prefer to rent furniture online rather than owning it. As per 'Furlenco', one of the largest online furniture rental company in India, $70 \%$ of their customer base are on the move due to job changes and do not stay at one place for more than two years. Occupational mobility influences the purchase behavior of a consumer to a great extent and online rental is no exception. Therefore we propose that:

\section{H5: Occupational mobility has the highest influence on the conversion rate of online furniture rental service}

\subsection{Complimentary Services}

Additionally, the present study conceptualized a new construct i.e. complementary service. Complementary services were identified as a construct during the pre-study. It is referred to as the services provided like installation, deinstallation, repair and delivery, free of cost in addition to renting a particular furniture. For example, customer renting a chest of drawer on Site 1. (India's largest online furniture rental portal), typically pays Indian Rupees (INR) 690,i.e., $\$ 9$ (\$1=INR 70.92) per month. The rental fees includes the delivery of the chest of drawer, and installation. Once the renting period is over, the furniture is de-installed and taken back by the service provider itself. Such services are termed as complementary services being provided by online furniture rental portals, as they are provided along with the main product. Complimentary Services as an attribute was identified through multiple focus group interviews and discussion with online rental users. Therefore, based on this qualitative research, we hypothesize that:

\section{H6: Complementary Services has the highest influence on the conversion rate of online furniture rental service}

\subsection{Conceptual Model}

The proposed model guiding the study (See Figure 1), which has been derived from a new form of consumption in the area of marketing, often termed as the collaborative economy or the sharing economy [1], [9], [51], [70]. The research model was developed based on conceptual and empirical studies in related disciplines. The model posits that customizations, perceived value, social gratification, psychological ownership, occupational mobility and complementary services will have an effect on actual usage i.e. conversion for online furniture renting.

The attributes such as customization, perceived value, social gratification, psychological ownership and occupational mobility have been taken from existing literature, whereas complementary service has been identified through a series of personal interviews and focus group discussion with industry experts and actual users. Conversion here is defined as final purchase, i.e., when a customer places an order through the mobile app or website of any of the online furniture rental provider, places the order and makes the payment, it is considered as a conversion. In case a customer scans through the products but does not make the final payment, it is not considered as a conversion.

\section{Research Methodology}

In order to test the suggested hypotheses, we initially conducted a pre study which was qualitative in nature. Subsequently, a quantitative data colelction method was employed using an online questionniare to test the proposed conceptual model. In this section, the research team describe the main steps in data collection as well as the tests conducted to check the reliability of the data. 


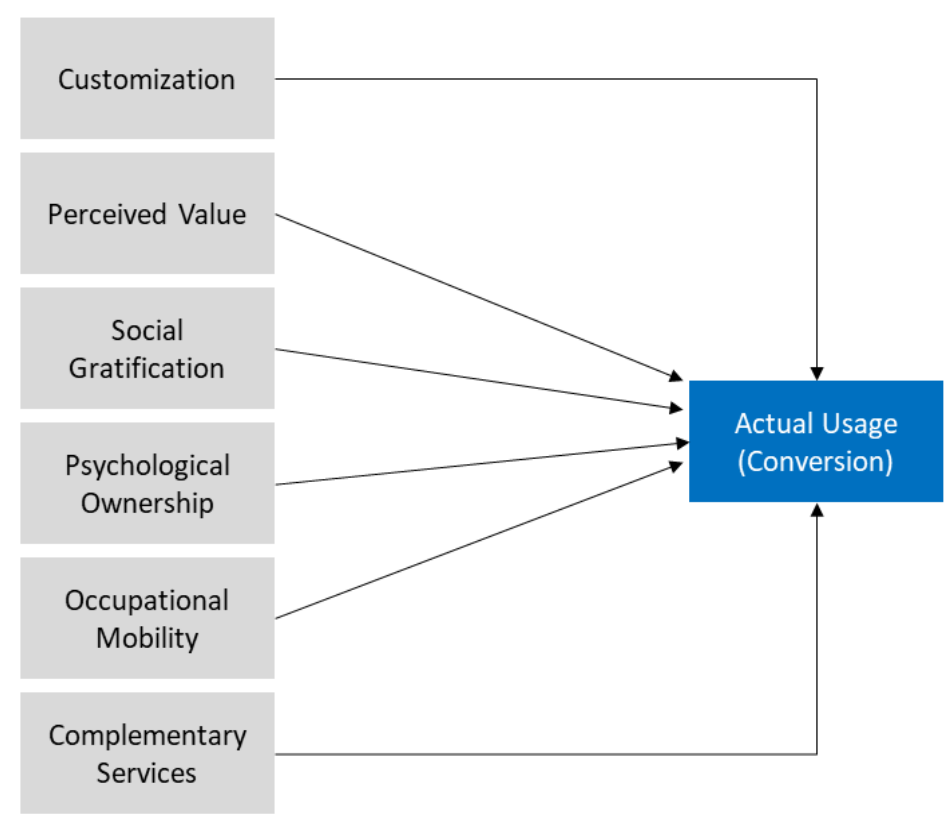

Figure 1: Conceptual model of study

\subsection{Pre Study: Qualitative Research}

The intent of the pre study was to identify key platform attributes from a customers' point of view. The pre study is based on a focus group study of individuals renting furniture online. Focus groups enable participants to talk about tacit knowledge and non-reflexive practices. By interacting with others, we shape and reshape our thoughts about things we do more or less consciously [35]. The detailed accounts and explanations given by the participants stimulate associations, which, in turn, produce a rich material [33]. This is particularly useful when studying the use of technology, for example, the web based platforms (for e.g., mobile apps or website) which are primarily a routine and unconscious action involving tacit knowledge. Finally, the focus group interview is also deemed appropriate in that it is a method capable of producing both breadth and depth of the collected empirical material in a short period of time [63], [100]. Focus groups are particularly appropriate for our purposes, since they bring in more insight into the study. This technique affords us the opportunity to observe the collective-sense-making of individuals with regards to online furniture rental, and also to generate a wider range of views, which is important for theorygeneration [16]. The research objectives are clearly subsumed within Fern's theory applications approach, by using focus groups to develop and (in part) confirm theory [46]. Seven focus group discussions were conducted, a number broadly consistent with similar research across various fields [63], [72]. Five of the focus group discussion were carried out with working professionals whereas two of the focus group discussions were carried out with University students based out of Delhi, Mumbai and Bangalore. Each focus group discussion consisted of at least 10 and at the maximum 17 members for the discussion. A total of thirty one (31) individuals from industry $(51 \%$ female mean age 33 years) and thirty six (36) university students (54\% male, mean age 26 years) were involved in the focus group discussions. The details of the participants involved in the focus group discussion are mentioned in Table 2.

Table 2: Profiles of focus group studies

\begin{tabular}{|l|l|l|l|l|l|}
\hline $\begin{array}{l}\text { Focus } \\
\text { Group }\end{array}$ & Males & Females & Occupation & Age & $\begin{array}{l}\text { Statements } \\
\text { Generated }\end{array}$ \\
\hline 1 & 5 & 5 & $\begin{array}{l}\text { Working } \\
\text { Professionals }\end{array}$ & $27-35$ & $\begin{array}{l}31 \text { Statements } \\
11 \text { Yes/No Statements }\end{array}$ \\
\hline 2 & 6 & 5 & $\begin{array}{l}\text { Working } \\
\text { Professionals }\end{array}$ & $27-35$ & $\begin{array}{l}42 \text { Statements } \\
10 \text { Yes/No Statements }\end{array}$ \\
\hline 3 & 4 & 6 & $\begin{array}{l}\text { Working } \\
\text { Professionals }\end{array}$ & $35-40$ & $\begin{array}{l}33 \text { Statements } \\
14 \text { Yes/No Statements }\end{array}$ \\
\hline 4 & 5 & 7 & $\begin{array}{l}\text { Working } \\
\text { Professionals }\end{array}$ & $35-40$ & $\begin{array}{l}39 \text { Statements } \\
11 \text { Yes/No Statements }\end{array}$ \\
\hline 5 & 4 & 8 & $\begin{array}{l}\text { Working } \\
\text { Professionals }\end{array}$ & $27-35$ & $\begin{array}{l}61 \text { Statements } \\
19 \text { Yes/No Statements }\end{array}$ \\
\hline 6 & 8 & 6 & University Students & $18-25$ & $\begin{array}{l}37 \text { Statements } \\
18 \text { Yes/No Statements }\end{array}$ \\
\hline 7 & 9 & 8 & University Students & $18-25$ & $\begin{array}{l}28 \text { Statements } \\
10 \text { Yes/No Statements }\end{array}$ \\
\hline
\end{tabular}


Compliant with the aim of this paper, the interviews focused on how, when and why participants use online portals or web based platforms for renting furniture. A semi-structured interview guide was used to ensure consistency in the questions asked across the focus groups [63]. Initially, the participants were asked to freely describe and discuss the use of their smart phones and devices such as laptops, tablets or desktops to explore renting furniture in terms of product and price. At different points, we raised specific questions like: What do you order using your smart phone/web browser? and How you zero down on a particular service provider, what attributes you look for, while surfing through the website or mobile app of a particular online furniture rental provider. Each focus group discussion lasted between 45 mins and 60 mins, and were recorded and fully transcribed. The moderator took notes throughout the sessions and these were transcribed afterwards.

Data were analyzed in an iterative process, alternating between data collection and analysis, often recommended in research focusing on social activities [16]. The analysis was conducted in four different phases. In the first phase, a systematic examination of the transcripts to identify individual items was conducted. During this first phase of the analysis, we searched for individual items for renting furniture online and coded various items. Forty eight items of online furniture rental were identified in this phase of the analysis. In the second phase, we searched themes for each of the items [87]. The forty eight items were categorized under seven broad themes. In the third phase, we identified different ways in which the participants discussed how multiple attributes for online furniture rental affected them. During the fourth phase, with the aid of academicians, attributes identified through literature were combined with the ones identified through the focus group discussion and tested through a pilot study. Finally, a total of 6 themes and 23 items were identified (Appendix A). Out of the six themes, five themes were related to the constructs, identified from pre-validated research namely customization, perceived value, social gratification, psychological ownership, occupational mobility and conversion. A new construct was proposed in the study, i.e., complementary services. Complementary services refer to the services provided to the customer by the online rental providers, in addition to the main product. For instance, providing free installation, de-installation and annual service, free of charge constitute the complementary services. For example, Furlenco provides free installation, assembly and deinstallation of products, when the total order value is greater than INR 700 (Approx \$10).

\subsection{Data Collection and Sample Characteristics}

Our study employed a survey of online shoppers to gather data for hypotheses testing and to address research objectives. The empirical part of this study was conducted in India using a questionnaire survey by surveying people who have bought second-hand furniture at least once through an online platform. Prior to the formal survey, a pilot study had been performed to test the questionnaire's design. Twenty nine individuals who (1) use a smart phone and (2) have rented furniture online in the last three months participated in the pilot study. All participants understood the instructions and wording of the survey clearly and no difficulties or issues relating to measurement items were reported. Accordingly, the questions did not need to be modified prior to the final survey. Before conducting the survey, we first considered the sample size. Stevens [90] suggested that the sample size for social science research should be greater than 15 times the number of predictors. There are 7 predictors in our model and the sample size should therefore be larger than 105. In addition, as we required the use of Structural Equation Modelling (SEM) to test the hypotheses, a sample size of at least 200 was necessary [41].

Data were collected using an online survey in SurveyMonkey for a period of two months starting July 2019. The general population in the metro areas of India especially Delhi (26 million residents), the capital and largest city; Mumbai (23 million residents), the second largest city; and Bangalore (12 million residents), the Information Technology (IT) hub of India, are individuals in the age bracket of $25-30$ Years, around $59 \%$ being males with majority of them having an undergraduate degree. The sample population for the current study are university students and working professionals from the said metro cities three metro cities. University students and working professionals were selected for three prime reasons. First, they are representative of the target population of a typical metro city from India; secondly, the consumer base for any of the online furniture rental platform consists primarily of either working professionals or university students. Third, by virtue of the nature of profession of the selected sample, they are more likely to rent furniture online in the future. In addition, the mentioned cities were chosen for the study for three main reasons (1) Total mobile downloads for Online Furniture Rental in India, is highest in Bangalore, Mumbai and Delhi [89]; (2) The total volume of orders across the major online furniture rental platform in India, i.e., Furlenco, RentoMojo and Citifurnish were highest from the said cities and (3) Delhi, Mumbai and Bangalore combined represent around $55 \%$ of the total smartphone users in India. In addition, around $76 \%$ of renting of furniture online (calculated in terms of absolute orders) in the last two year, took place in Delhi, Mumbai and Bangalore.

Subsequently, an invitation email with a link to the survey site was sent to 704 participants across the three identified cities. In the beginning of the survey, respondents were asked whether they had rented furniture online in the last three months. Respondents with a No were excluded from the study. By excluding the non-shoppers, it ensured that all the remaining respondents were online shoppers who had rented furniture online either through mobile apps or company website. During the two months starting July 2019, the required data was collected from a convenience sample size of 341 smartphone users who had already adopted and rented furniture online (i.e., Furlenco, Fabrento, RentoMojo and Cityfurnish). 
A total of 399 responses were collected, which yielded a response rate of $48 \%$. Each questionnaire was scrutinized and eliminated if it had too many missing values. There were a total of 53 incomplete responses. Out of the incomplete responses, 35 respondents had only filled in the profile details and did not attempt the questionnaire whereas the remaining respondents $(n=18)$ had answered only 3-6 questions from the survey. As a result, 53 questionnaires were eliminated from the survey and finally, we obtained 341 valid responses, which fulfilled the requirements of sample size mentioned above. Among them, $56.5 \%$ were female and $43.5 \%$ were male. The majority of respondents were between 28 and 35 years old $(68.1 \%)$. More than half $(68.0 \%)$ held a master's degree. More than half of the respondents $(71.4 \%)$ reported experience of online shopping of more than two years. The most frequently used platform for online furniture rental included Furlenco (41.2\%), RentMojo (27.8\%) and Citifurnish (11). More details about the demographics of the sample and purchase behavior are presented in Table 3.

Table 3: Demographic characteristics of respondents

\begin{tabular}{|l|l|l|l|}
\hline Demographic & Category & $\begin{array}{l}\text { Number of Respondents } \\
(\mathbf{N = 3 4 1})\end{array}$ & Percentage (\%) \\
\hline Gender & Male & 193 & 56.5 \\
\hline & Female & 148 & 43.5 \\
\hline Age & $18-21$ & 38 & 11.1 \\
\hline & $22-30$ & 107 & 31.3 \\
\hline & $31-39$ & 165 & 48.4 \\
\hline Education Level & $40+$ & 31 & 9.2 \\
\hline & Bachelor & 132 & 38.8 \\
\hline & Post Graduates & 170 & 49.9 \\
\hline Mobile Shopping Experience & Others & 39 & 11.3 \\
\hline & $<1$ year & 40 & 11.8 \\
\hline & $1-3$ years & 119 & 34.9 \\
\hline & $3-5$ years & 161 & 47.1 \\
\hline Online Furniture Renting Experience & $5+$ years & 21 & 6.2 \\
\hline & $<1$ year & 85 & 24.8 \\
\hline & $1-3$ years & 123 & 36 \\
\hline Average Order Value (in INR) & $3+$ years & 134 & 39.2 \\
\hline & $>\$ 10$ & 58 & 17.1 \\
\hline & $\$ 10-\$ 20$ & 133 & 38.9 \\
\hline & $\$ 20-\$ 30$ & 105 & 30.8 \\
\hline Order Medium & $\$ 30+$ & 45 & 13.2 \\
\hline & Mobile App & 236 & 69.1 \\
\hline & Website & 105 & 30.9 \\
\hline
\end{tabular}

1 US $\$=71.46$ INR as of Nov 11,2019

\subsection{Questionnaire Design}

A total of 23 items were used to measure the seven constructs in the proposed research model. We measured the main constructs as first-order reflective constructs with multiple reflective indicators adapted from previous studies and the pre study. Specially, three items of customization were adapted from [91]; three items of perceived value were adapted from [99], four items of social gratification were adapted from the study of [65]; three items of psychological ownership were adapted from [29] whereas four items pertaining to occupational mobility and two ítems for conversion were adapted from the works of [43]. Items from previous studies along with items from the pre study were combined and modified to fit in our current research context (See Appendix A).

All 23 item responses were reported on a 7-point Likert scale (1=strongly disagree; 7=strongly agree). Before finalizing the survey tool, we pre-tested the questionnaire with 21 undergraduate students at University of Delhi, India and eight research scholars from management department, who confirmed the clarity of the questions and validity of the instrument. We made minor modifications to the wording of some questions before the questionnaire was finalized and distributed. Based on the feedback gained from the pretest, all the 23 items adequately represented the intended constructs. Hence, the scales used in this study achieved face validty. In summary, individual characteristics and online furniture rental attributes, emerging from this research phase consisted of 23 items clustered under six constructs, categorized as below:

1. Customization(CUST) [3 items, alpha $=0.911]$ 
2. Perceived value (PV) [3 items, alpha $=0.861]$

3. Social gratification (SG) [4 items, alpha $=0.848$ ]

4. Psychological ownership (PSYO) [3 items, alpha $=0.908]$

5. Occupational mobility $(\mathrm{OM})[4$ items, alpha $=0.875]$

6. Conversion (CONV) [2 items, alpha $=0.901]$

7. Complementary Services (CS) [4 items, alpha $=0.916]$

\section{Results}

The results section will begin by providing preliminary descriptive statistics of the variables considered for the study. It will then present the two-stage structural equation modelling (SEM) that was adopted to validate the conceptual model and test its associated hypotheses. The results of the confirmatory factor analysis (CFA) in the first stage are presented in the subsequent section, followed by the structural model, the second stage of the SEM results.

\subsection{Descriptive Statistics of the Scale Items}

Table 4 shows the mean and standard deviation for all the items used in the questionnaire. Overall, individual characteristics as well as platform attributes seem to have a string influence towards online furniture renting. For example, users of online furniture rental positively perceived online renting in terms of customization (platform attribute), as the average mean for three items was 6.60 with an average standard deviation value of 0.595 . The average mean of occupational mobility (individual characteristics) was 6.25 (0.724), which expresses a positive perception among users, changing geographic location due to work. Positive perception was also noticed among the study participants regarding complementary services (platform attribute). Similarly average mean values of psychological ownership (individual characteristics) items (0.739) indicate the negative role of psychological ownership for the current study participants. Renting furniture online seemed to be more gratifying and socially acceptable (individual characteristics) for the respondents. The vast majority of the participants perceived renting furniture 'online' as reasonably priced (platform attribute), as all items of price value had an average mean value of $6.12(0.637)$. Likewise, respondents seem to have been motivated to continue renting furniture online.

Table 4: Descriptive statistics of the scale items (Mean and standard deviation)

\begin{tabular}{|c|c|c|c|}
\hline Construct & Items & Mean & Standard Deviation \\
\hline \multirow[t]{3}{*}{ Customization } & CUST1 & 6.76 & 0.581 \\
\hline & CUST2 & 6.54 & 0.575 \\
\hline & CUST3 & 6.51 & 0.628 \\
\hline Average & & 6.6 & 0.595 \\
\hline \multirow[t]{4}{*}{ Social Gratification } & SG1 & 6.45 & 0.830 \\
\hline & SG2 & 6.32 & 0.676 \\
\hline & SG3 & 6.11 & 0.589 \\
\hline & SG4 & 6.09 & 0.767 \\
\hline Average & & 6.24 & 0.716 \\
\hline \multirow[t]{4}{*}{ Occupational Mobility } & OM1 & 6.43 & 0.841 \\
\hline & OM2 & 6.29 & 0.761 \\
\hline & OM3 & 6.18 & 0.677 \\
\hline & OM4 & 6.11 & 0.617 \\
\hline Average & & 6.25 & 0.724 \\
\hline \multirow[t]{3}{*}{ Perceived Value } & PV1 & 6.79 & 0.615 \\
\hline & PV2 & 6.54 & 0.716 \\
\hline & PV3 & 6.39 & 0.817 \\
\hline Average & & 6.57 & 0.716 \\
\hline \multirow[t]{3}{*}{ Complementary Services } & CS1 & 6.21 & 0.871 \\
\hline & CS2 & 6.1 & 0.678 \\
\hline & CS3 & 6.01 & 0.786 \\
\hline
\end{tabular}




\begin{tabular}{|c|c|c|c|}
\hline & CS4 & 5.99 & 0.640 \\
\hline Average & & 6.08 & 0.744 \\
\hline \multirow[t]{2}{*}{ Conversion } & CONV1 & 6.88 & 0.567 \\
\hline & CONV2 & 6.78 & 0.786 \\
\hline Average & & 6.83 & 0.677 \\
\hline \multirow[t]{3}{*}{ Psychological Ownership } & PSYO1 & 2.77 & 0.875 \\
\hline & PSYO2 & 2.54 & 0.587 \\
\hline & PSYO3 & 2.43 & 0.756 \\
\hline Average & & 2.58 & 0.739 \\
\hline
\end{tabular}

\subsection{Measurement Model}

The first stage involved testing the model's fitness using CFA. Seven common model-fit measures were used to assess the model's overall goodness of fit: the ratio of $\mathrm{X} 2$ to degrees-of-freedom (df), comparative fit index (CFI), goodness of fit index (GFI), adjusted goodness-of-fit index (AGFI), normalized fit index (NFI), Tucker-Lewis index (TLI) and mean square error of approximation (RMSEA) [17], [36], [92]. Table 5 presents the results of these tests.

Table 5: Fit indices for measurement and structural model

\begin{tabular}{|l|l|l|l|}
\hline Fit Indices & Recommended Values & Measurement Model & Structural Model \\
\hline $\mathrm{X} 2 / \mathrm{df}$ & $\leq 3.00$ & 2.543 & 2.539 \\
\hline $\mathrm{CFI}$ & $\geq 0.90$ & 0.954 & 0.953 \\
\hline GFI & $\geq 0.90$ & 0.909 & 0.908 \\
\hline $\mathrm{AGFI}$ & $\geq 0.80$ & 0.853 & 0.851 \\
\hline $\mathrm{NFI}$ & $\geq 0.90$ & 0.929 & 0.927 \\
\hline TLI & $\geq 0.90$ & 0.927 & 0.926 \\
\hline RMSEA & $\leq 0.08$ & 0.057 & 0.056 \\
\hline
\end{tabular}

As shown in Table 5, all the model-fit indices exceeded the respective common acceptance levels suggested by previous research, demonstrating that the measurement model exhibited a good fit with the data collected. Therefore, we proceeded to evaluate the psychometric properties of the measurement model in terms of reliability, convergent validity, and discriminant validity. Reliability and convergent of the factors were estimated by composite reliability (CR) and average variance extracted (AVE) (see Table 6). CR for all factors in our measurement model was above 0.70. The AVEs were all above the recommended 0.50 level; which meant that more than one-half of the variances observed in the items were accounted for by their hypothesized factors. Convergent validity can also be evaluated by examining the factor loadings from the CFA. Following the recommendations of Hair et al. [37], factor loadings greater than 0.50 were considered to be very significant. All of the items in the research model had factor loadings greater than 0.70. In addition, all Cronbach Alpha values were larger than 0.7 [57], suggesting a good reliability [68]. Thus, all the factors in the measurement model had adequate reliability and convergent validity [58].

Table 6: Discriminant validity of measurement model

\begin{tabular}{|l|l|l|l|l|l|l|l|}
\hline & CUST & SG & OM & PV & CS & CONV & PSYO \\
\hline CUST & $\mathbf{0 . 9 3 5}$ & & & & & & \\
\hline SG & 0.712 & $\mathbf{0 . 9 0 7}$ & & & & & \\
\hline OM & 0.671 & 0.448 & $\mathbf{0 . 9 5 0}$ & & & & \\
\hline PV & 0.612 & 0.431 & 0.678 & $\mathbf{0 . 9 4 2}$ & & & \\
\hline CS & 0.564 & 0.376 & 0.612 & 0.687 & 0.885 & & \\
\hline CONV & 0.512 & 0.377 & 0.587 & 0.654 & 0.578 & $\mathbf{0 . 9 5 2}$ & \\
\hline PSYO & 0.487 & 0.376 & 0.470 & 0.578 & 0.523 & 0.455 & $\mathbf{0 . 9 3 6}$ \\
\hline
\end{tabular}

Several criteria were adopted to test the reliability and validity of the constructs, namely composite reliability (CR), Cronbach's alpha, average variance extracted (AVE), and discriminant validity [32], [38]. The convergent validity was also tested by looking at the factor loading value extracted by each scale item (Hair et al., 2010). To examine 
discriminant validity, we followed the method suggested by Fornell and Larcker [32]. We compared the square root of the AVE of each construct and its correlation coefficients with other constructs. The results in Table 7 showed that the square roots of the AVEs were larger than the corresponding correlation coefficients, thus showing sufficient discriminant validity. In summary, the measurement model demonstrated adequate reliability, convergent validity, and discriminant validity.

Table 7: Standardized item loadings, AVE, CR and Cronbach's alpha values

\begin{tabular}{|l|l|l|l|l|l|}
\hline Construct & Items & Standardized item loadings & AVE & CR & Cronbach's alpha \\
\hline Customization & CUST1 & 0.912 & 0.874 & 0.914 & 0.911 \\
\hline & CUST2 & 0.818 & & & \\
\hline & CUST3 & 0.891 & & & \\
\hline Social Gratification & SG1 & 0.876 & 0.823 & 0.867 & 0.848 \\
\hline & SG2 & 0.817 & & & \\
\hline & SG3 & 0.798 & & & \\
\hline Occupational Mobility & SG4 & 0.799 & & & \\
\hline & OM1 & 0.912 & 0.903 & 0.889 & 0.875 \\
\hline & OM2 & 0.901 & & & \\
\hline & OM3 & 0.9 & & & \\
\hline Price Value & OM4 & 0.899 & & & \\
\hline & PV1 & 0.888 & 0.888 & 0.901 & 0.861 \\
\hline & PV2 & 0.889 & & & \\
\hline Complementary Services & CS1 & 0.786 & & & \\
\hline & CS2 & 0.768 & 0.784 & 0.923 & 0.916 \\
\hline & CS3 & 0.796 & & & \\
\hline & CS4 & 0.786 & & & \\
\hline CONV1 & 0.91 & & & \\
\hline Conversion & CONV2 & 0.901 & 0.906 & 0.910 & 0.901 \\
\hline Psychological Ownership & PSYO1 & 0.917 & & & \\
\hline & PSYO2 & 0.897 & & & \\
\hline & PSYO3 & 0.812 & & & \\
\hline & & & & & \\
\hline
\end{tabular}

To examine the potential common method bias, we performed two statistical analyses to assess the severity of common method bias. First, a Harman's single-factor test suggested by Podsakoff et al. [75] was conducted on the four constructs. We found that no single-factor emerged and the first factor accounted for $21.7 \%$ of the $78.9 \%$ explained variance. Second, the study conducted a CFA to assess the fit of a single-factor model (all items loading on one factor). The single-factor model showed a very poor fit $(X 2 / \mathrm{df}=5.6, \mathrm{CFI}=0.712, \mathrm{GFI}=0.490, \mathrm{NFI}=0.563$, $T L I=0.541, \mathrm{RMSEA}=0.23$ ). Both tests confirmed the absence of common method bias.

\subsection{Structural Model}

The research hypotheses of the conceptual model were all tested in the second stage using SEM. A similar set of fit indices was used to examine the structural model. Comparison of all fit indices, with their corresponding recommended values, provided evidence of a good model fit $(X 2 / d f=2.539, \mathrm{CFI}=0.953, \mathrm{GFI}=0.908, A G F I=0.851$, $\mathrm{NFI}=0.927, \mathrm{TLI}=0.926, \mathrm{RMSEA}=0.056$ ). Thus, we could proceed to examine the path coefficients of the structural model. Fig. 2 displays the standardized path coefficients, path significances, and variance explained $\left(R^{2}\right)$ by each path. 


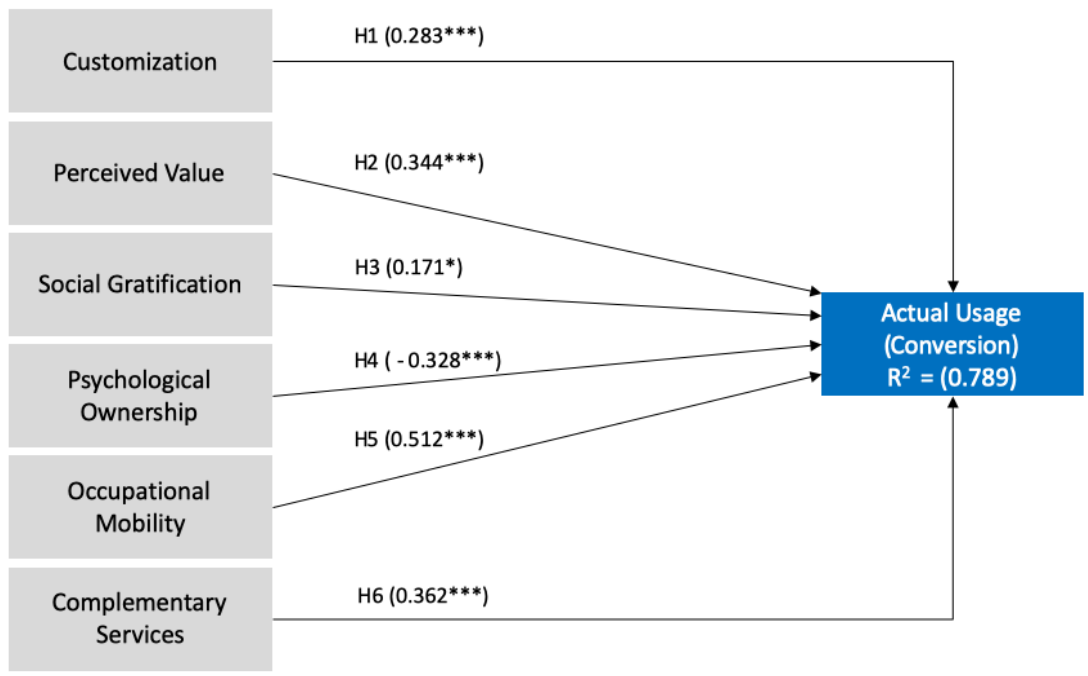

Figure 2: Results estimated by AMOS

(Note ${ }^{*} P<0.05,{ }^{* *} P<0.01,{ }^{* * *} P<0.0001$ )

The results (see Figure 2) show that the hypotheses $\mathrm{H} 1, \mathrm{H} 2, \mathrm{H} 3, \mathrm{H} 5$ and $\mathrm{H} 6$ are well supported, however $\mathrm{H} 4$ is not supported based on the proposed model. Five of the paths proposed are significant, with a p-value of less than 0.05 . Occupational mobility positively affected conversion $(\beta=0.512, p<0.000)$, confirming $\mathrm{H} 5$. Complementary services has a significant positive effect on conversion $(\beta=0.362, p<0.01, \mathrm{H} 6$ supported). Perceived value is positively associated with conversion $(\beta=0.344, p<0.01, \mathrm{H} 2$ supported) followed by Customization $(\beta=0.283, p<0.01, H 1$ supported) and Social gratification $(\beta=0.171, p<0.01, \mathrm{H} 3$ supported). However, the impact of psychological ownership $(\beta=0.171, p<0.01)$ had a negative effect on the conversion $(\beta=0.08, p<0.838$, H4 not supported).

Table 8: Results of Hypotheses Testing.

\begin{tabular}{|l|l|l|l|l|l|l|l|l|}
\hline$\#$ & Hypothesized path & Estimate & S.E. & C.R. & P & VIF \\
\hline H1 & Conversion & $<---$ & Customization & 0.283 & 0.041 & 1.595 & ${ }^{* *}$ & 1.351 \\
\hline H2 & Conversion & $<---$ & Perceived Value & 0.344 & 0.081 & 0.065 & ${ }^{* * *}$ & 1.421 \\
\hline H3 & Conversion & $<---$ & Social Gratification & 0.171 & 0.036 & 1.19 & ${ }^{*}$ & 2.871 \\
\hline H4 & Conversion & $<---$ & $\begin{array}{l}\text { Psychological } \\
\text { Ownership }\end{array}$ & -0.328 & 0.022 & 0.309 & $* * *$ & 1.19 \\
\hline H5 & Conversion & $<---$ & Occupational Mobility & 0.512 & 0.112 & 0.523 & ${ }^{* * *}$ & 2.541 \\
\hline H6 & Conversion & $<---$ & $\begin{array}{l}\text { Complementary } \\
\text { Services }\end{array}$ & 0.362 & 0.093 & 0.478 & ${ }^{* * *}$ & 2.765 \\
\hline
\end{tabular}

To ensure that there was no multicollinearity problem among the independent factors (Customization (CUST), Social Gratification (SG), Occupational Mobility (OM), Perceived Value (PV), Complementary Services (CS) AND Psychological Ownership (PSYO) and dependent factors Conversion (CONV), variance inflation factors (VIF) were tested. Table 8 shows that VIF values for all causal associations were not higher than 10, which mean that there is no concern regarding multicollinearity [15], [24].

\section{Discussion and Implications}

Due to the growing phenomenon of access-based consumption, particularly in the fashion industry, it is important to understand how consumers can be engaged in collaborative consumption and with the increasing popularity of web based platforms, marketing scholars and practitioners have recognized that online rental platforms are effective digital communication and consumer engagement tools to drive collaborative consumption. To explore the role of online portals or web based platforms for online furniture rental, the current study developed and empirically tested a model to examine how online furniture rental providers influence the rental decision of a consumer and subsequently lead to conversion. Specifically, we provided empirical evidence that customization, perceived value, social gratification, psychological ownership, occupational mobility and complementary services have a significant effect on conversion.

Among the factors resulting in conversion, occupational mobility had the highest effect on conversion $(\beta=0.512)$. Occupational mobility refers to change in current geographic location of an individual due to a career movement. The positive relationship between occupational mobility and purchasing power is consistent with the findings of Liang and Lu [55], which asserted that consumer's purchasing power increases due to occupational mobility for better quality of 
life. Mobility of the younger generation has increased exponentially in the last few years [66]. They are exploring cities and haven't made up their minds on where to settle and want to access every product and service [76]. Renting provides customers with a hassle free experience as long as they want. Customers who relocate to cities for work usually prefer to rent all the furniture they want and for as long as they want. Furniture that one might need today may not be required tomorrow. As a result, furniture rental often eases the relocation stress for employees and families in transition, and provides an alternative to the high cost of shipping furniture to support temporary assignments. It was found in the study that working professionals (Average age: 32 years) preferred to rent furniture the most, of all the other segments. Around $60 \%$ of the respondents had changed their respective jobs in the last two years and moved to a different geographic location. As a result buying new furniture or transporting the old furniture to the new city is not always a viable option. As a result, renting furniture online is the best option due to relocation of individuals. It is convenient, time saving and above all cost effective. Since occupational mobility has the highest influence on conversion, online furniture rental platforms should design exclusive plans and promotions for segment of consumers, relocating to different geographic locations, frequently.

We found that addition to occupational mobility, complementary services also significantly affects conversion $(\beta=0.362)$. The argument is supported by Küster et al. [47] who state that pre and post purchase services have a positive relation with loyalty, improves customers experience and results in conversion. Online furniture rental platforms provide complementary services such as free assembly, swap, installation and de-installation. The cost of assembling of furniture is included in the monthly rental and covers the logistics cost as well. For example, a bed worth \$558 (approx. INR 50,000) when purchased offline would cost around $\$ 30$ (approx. INR 2,000) for transportation and additional \$ 30 (approx. INR 2,000) for assembling, under normal circumstances. In addition, the customer would have to bear the cost transportation, in case any defect or service is retired for the furniture. Now, when the same furniture (in terms of design, color, utility and brand) is rented online, the monthly rental comes around \$ 14 (approx. INR 1000) per month which is inclusive of transportation and assembly. In addition, whenever the customer wants to discontinue with the bed, they can place a request and the bed would be de-installed and taken back, free of charge. Even if any service request is made, during the rental period, it is completed free of charge.

Our study revealed that perceived value had the third highest influence on conversion $(\beta=0.344)$. Renting provides value for money and is as much about saving money as they are about convenience. Some of the products that are given on rent come at just $1-2 \%$ of the original cost of the product, making it accessible for many more (Co-founder, RentoMojo). In simple words the amount spent on purchasing a piece of furniture can be used to buy several pieces over a period of time and eventually buying the best amongst the lot, that too at a discounted price. For example, someone who wishes to purchase a 3+2 sofa set for their drawing room. Now typically, a 3+2 sofa set would range between \$ 625 - \$ 972 (INR 45,000 - INR 70,000). The rent value for such a soft set would come to around \$ 9 (approx. INR 650) per month. Renting provides the consumer with an option of renting a sofa set for a specific period of time and in addition providing an option to change the design over a period of time. Consumers see a value in renting vis-à-vis purchase since the price value for renting not only in terms of money but in terms of convenience and ownership is higher. Results for perceived value indicate that individuals are inclined to second hand products due to the price advantage as compared to brand new products [82].

Customization was also found to have a positive effect on renting furniture online $(\beta=0.283)$. Customization drives impulse purchase and increase in revenue [31]. Empowered by social networks and smartphones, consumers are dictating what they want, when and where they want it. Modern consumers expect the ability to customize anything and everything to fit their individual preferences. Consumers are demanding a more personalized service and expect to be given the opportunity to shape the products and services they consume. The demand for customized products and service will continue to increase as market becomes affluent [25]. Though customization has the least effect on conversion, but consumers are expecting, if not demanding, highly personalized experiences [31]. Modern consumers expect the ability to customize anything and everything to fit their individual preferences [26]. The findings are consistent with the findings of Forbes [31] who states that customers are impressed by customization of products and tend to spend more. It is also argued that well executed customization can deliver eight to five times the return on investment on marketing spend [26]. As sustainable fashion becomes a necessity as well as a trend, shoppers are looking to fill their home in different ways. For example, Furlenco offers a product to the customer called THE POD; which is a bed-cum-TV-cum entertainment system-cum-bluetooth connectivity and charger. It is an all-in-one product which doesn't exist in the market. As a result, customers prefer such products since they are customizable as per the requirement of the customers, making them unique and at the same time high on utility. Customizing furniture is an option which is hardly provided by any of the offline retailers and in a time. Online furniture rental provides something that none of the companies offer in the offline space, i.e., customizable design and tenure, for majority of products. Thus,social gratification was found to be the next most important attribute resulting in conversion $(\beta=0.171)$. The positive relationship between social gratification and conversion is consistent with name of the study $i$ ?? [53] stating that social interaction and influence persuade buyers to rent online. Individuals sense instant gratification, on being asked for recommendation and suggestions for online renting, from peer groups. The growing fashion sense among the new generation, owning to social media such as Instagram, is propelling growth of the shared economy. Today customers want new looks for their interiors, want to use fashion furniture much frequently, and every month in some cases. Renting furniture usually costs between 2-3\% of the retail price of furniture. As a result, renting high end furniture gives a sense of pride to the customer and also the feeling of rationality in terms of price value. The online furniture rental platforms (ORFP's) have made renting 
furniture more exciting for people. Customers can pay for as long as they use and then give it back and take something else or move on. It's all about meeting the lifestyle of customer in today's time [26]. For example, customers can use the products till the time they want on the basis of monthly rentals. When they are certain about where they want to live for a longer time, they can own the products at a discounted price. In addition, the feeling of owning a living space which leaves an impression on others is on the rise. Home ambience and décor play very important roles in today's time. Home décor represents one's personality and individuals display their edge and personality through their home space itself. As a result, renting furniture which is attractive in design and yet has a higher utility is aspired by many. Buying several pieces of furniture is not only risky but also involves heavy investment. In such cases, renting is a safer option.

Psychological ownership however, had a negative relation with conversion $(\beta=-0.328)$. People who purchase new furniture have a sense of belonging for the furniture and do not mind investing in furniture. They consider furniture as assets and use them for over decades. The findings are consistent with that of Moeller and Wittkowski [60] who stated that non-ownership services is negatively influenced by possession importance, i.e., consumers are attached to products with full ownership as compared to temporary ownership. Research by Bagga et al. [7] also confirmed that rented objects are not valued higher than possessed objects. It was found during the study that individuals who prefer to purchase furniture are not fully convinced with the idea of renting. They cannot image renting furniture especially, if it has been used by other. Respondents did not prefer to sleep on a bed, which has been used by someone else. Therefore consumers who rented online had no sense of ownership towards the rented products and hence did not affect the conversion.

This study makes several important contributions to research. Firstly, as far as our knowledge is concerned, this study is one of the very few that has attempted to investigate the relationship between online portals or web based platform attributes and conversion for online rental service provider. As noted earlier, extant research has focused on consumers' initial adoption and acceptance of mobile apps or website, and has seldom considered attributes of a web based platform, which is critical to online furniture rental platform's (OFRP) success. In this regard, this study contributes to existing literature by providing new insights into web-platform attributes of online furniture rental providers and their effects on conversion, i.e., actual purchase by customers. In addition, as discussed in the literature review, only a limited number of studies have tested issues relating to online furniture rental [10], [45], [69]. Moreover, the perspective on online furniture rental of Indian customers requires deeper understanding, especially given the lack of any studies either on India or any emerging economy. Therefore, this study makes a valuable contribution by expanding the current understanding regarding the main aspects pertaining to furniture rental in the online space, either in India or worldwide. Secondly, with the help of a series of focus group discussion with users renting furniture in the online space, a new dimension of complementary services was identified. A complementary service is a construct which has evolved with the online commerce industry. With more and more focus on collaborative consumption, making it convenient and hassle free for consumers, to rent products online in a seamless manner has emerged as a strategic step for online rental platforms worldwide. Thirdly, prior studies on web-based attributes largely ignored the operational aspects of web-based platforms and focused more on the adoption levels [28]. Previous research has mainly adopted Technology Acceptance Model (TAM) and Unified Theory of Acceptance and Use of Theory (UTAUT) as a theoretical basis and investigated the roles of instrumental beliefs such as perceived usefulness and performance expectancy in determining mobile app attributes. However, mobile shopper behavior is not only affected by perceived usefulness and performance expectancy which are extrinsic motivations, but also by mobile attributes, which is an intrinsic motivation that places emphasis on shopping process. Similar to what previous studies' findings that have shown among online shopping consumers [43], [44], [54].

Besides its contribution to the theory, this study provides more practical and empirical understanding about the main attributes that should be considered in designing and marketing online renting platforms. From a managerial point of view, this study offers salient insights for online platforms and marketers regarding retaining of existing users and facilitation of higher conversion. For instance, the study reveals that occupational mobility has a greater impact on conversion for renting furniture online. Therefore designing campaigns which resonates with the requirements of individuals relocating to other locations would not only create interest but also lead to higher conversion. In addition, creating customized offerings for consumers with higher occupational mobility, for instance providing free delivery on next relocation, i.e. , whenever an individual relocates in future, the logistics of rented furniture would be taken care of by the online rental platform. This will not only create stickiness towards the brand but would also increase conversion i.e. renting more and more on the same platform. Companies can come up with engaging subscription plans; for example, yearlong free delivery, unlimited furniture swaps etc., exclusively for customers high on occupational mobility, thus leading to higher conversion. Online rental platforms should also create customized offerings in terms of product design, in order to increase conversion. Customization was found to increase conversion towards online rentals, therefore providing option to customers; to customize their products in terms of colors, sizes and material, would not only increase conversion but would also create positive word of mouth for online rental platforms. Markets can design marketing campaigns and let them run for a couple weeks, and then analyze the results. This way, they will have an accurate impression of actual progress over time, rather than a quick snapshot into how their customization strategy is progressing. Perceived value was found to increase conversion i.e. renting online furniture due to multiple values such as convenience, low cost and flexibility etc. derived through renting. As a result, the online rental platforms should provide greater services through their channels in order to increase the value perceived by customers. For example, including description about the product durability and 
functionality, sellers' ratings, certifications of the product, and by providing assurances for the reduced chances of a product malfunction, which are largely ignored by the online platforms [70], in order to increase conversion and motivate newer customers to rent online. Psychological ownership for customers, who do not wish to rent furniture, companies can come up with Try an item strategy wherein customers can request for furniture on a trial period, free of cost. If the customers are happy with the product and service, they can rent the furniture by paying for the subsequent month. This will not only instill confidence within the customers towards renting but also encourage them to try low value furniture which has a lower psychological ownership. If the customers find value in the rented furniture, the psychological ownership would eventually reduce and increase conversion. Regarding social gratification, online rental platforms need to encourage customers to visit the web portals and view picture posted by other users. Company's web portals or mobile apps should consist of high-quality images clicked professionally and beside the product images; they should also have a place to display customers' photos who previously rented them. This will allow users to imagine, how the rented furniture would improve the décor of one's rooms, which in turn would increase their social interaction, thus leading to higher acceptability. For complementary services, companies should include complete the look section on their web portals or mobile apps that suggests supplementary accessories and services, being provided to customers. Since complementary services is found be positively related to conversion, a detailed view of all complementary services which can be provided to the customers, would in turn improve the conversion process. Therefore, occupational mobility, complementary services, perceived value and social gratification are the influential attributes which need to be factored in, while designing an effective web based or mobile strategy for online furniture rental platforms.

\section{Conclusion}

This study has attempted to provide more understanding regarding the aspects that could shape Indian customers' behavior towards online furniture rental platforms (OFRPs). A close review of online renting illustrates that previous research has seldom examined the continued intention towards online renting. However, retaining customers and facilitating their continued purchase are crucial for OFRPs. Thus, the purpose of this study was to examine various attributes of online furniture rental platforms towards conversion. We proposed and empirically examined an integrated model that explains attributes of online furniture rental platforms and final conversion. The results indicated that occupational mobility, psychological ownership, complementary services, social gratification, price value and customization affect the conversion for online furniture rental platforms. In addition, a new construct, i.e., complementary services was identified through focus group discussion which in-turn affected conversion. The results imply that online furniture rental platforms need to design a platform which not only provides value to the customers but influences their lifestyle as well and eventually result into conversion. The data was then analyzed using SEM and the results largely supported the validity of the current study's model by confirming the influence of the most significant of the proposed factors on conversion. A rich discussion of the findings was presented in the light of the particular nature of OFRPs, the furniture context, and India. Further explanation and discussion were provided about the theoretical contributions and practical implications of this study.

\section{Limitations and Future Scope}

Although this research contributes to the growing body of rental shopping literature, the findings should be interpreted with caution. First, we conducted this research in India, where online renting is developing rapidly especially in the urban areas, but is still in its infancy stage. Thus, it may be difficult to generalize the study's findings to other parts of India, especially semi-urban areas (typically Tier 2 and 3). Hence, future research could garner a larger number of participants, in addition to utilizing a randomized sampling technique.

Secondly, besides the factors identified in this study, there may be other factors affecting conversion towards online rental platforms. It would be interesting for future studies to integrate the role of moderating individual characteristics, like satisfaction with collaborative practices, for a more detailed analysis. We can also consider the moderating effect of platform type. Platforms can be mobile (Mobile apps) or desktop/laptop (websites dedicated to online renting). The type of the product sold could also be a moderating variable. For instance, how conversion for living room furniture like sofa set differs from that of bed room or kids' room, like beds. In addition, we have focussed on just one type of collaborative consumption platform. Further testing the model in other online sharing contexts such as clothes and apparel, etc., is recommended. Testing the model in other contexts may create different usage patterns and further identify determinants for building a successful sharing platform.

Thirdly, this sample remains limited. The sampling strategy for the quantitative survey under-represented certain population groups, limiting the generalizability of the findings. Our survey sample was controlled to only users of web based platforms such as Furlenco, etc. To focus on the online renting process, we only focused on potential users which naturally confines our sample to smartphone and internet users. Adding participants from a wider geographic area could provide more themes to expand the theory.

Future research should go beyond the Indian market, compare different online furniture rental markets, and use more sophisticated sampling strategies, at best representative of the whole furniture rental user base. 
Lastly, the service aspect of online furniture renting has not been covered in the study. Once the order is delivered, the experience with the rented furniture, assembly, de-installation, etc., have not been taken into consideration. Future studies can be designed in such a manner that the pre-purchase as well as post-purchase attributes are identified and measured.

\section{Acknowledgement}

We are truly grateful to Faculty of Management Studies, University of Delhi, India for providing us with a promoting environment to carry out our research. We also acknowledge the support of Indian Council of Social Science Research (ICSSR), Delhi for providing us with the required support in carrying out the research.

\section{Website List}

Site 1: Furlanco www.furlenco.com

\section{References}

[1] I. Abbes, Y. Hallem and N. Taga, Second-hand shopping and brand loyalty: The role of online collaborative redistribution platforms, Journal of Retailing and Consumer Services, vol. 52, no. 101885, pp. 1-11, 2019.

[2] A. Acquier, T. Daudigeos and J. Pinkse, Promises and paradoxes of the sharing economy: An organizing framework, Technological Forecasting and Social Change, vol. 125, no. 6, pp. 1-10, 2017.

[3] A. A. Alalwan, N.P. Rana, Y.K. Dwivedi, and R. Algharabat, Social media in marketing: A review and analysis of the existing literatura, Telematics and Informatics, vol. 34, no. 7, pp. 1177-1190, 2017.

[4] A.A. Alalwan, Mobile food ordering apps: An empirical study of the factors affecting customer e-satisfaction and continued intention to reuse, International Journal of Information Management, vol. 50, no. 1, pp. 28-44, 2020.

[5] E.W. Anderson, C. Fornell and R.T. Rust. Customer satisfaction, productivity, and profitability: Differences between goods and services, Marketing Science, vol. 16, no. 2, pp. 129-145, 1997.

[6] M. Amirpur and A. Benlian, Buying under pressure: Purchase pressure cues and their effects on online buying decisions, in Proceedings of the 36th International Conference On Information Systems (ICIS 2015), Fort Worth, USA, Dec 2015.

[7] C.K. Bagga, N. Bendle and J. Cotte, Object valuation and non-ownership possession: How renting and borrowing impact willingness-to-pay, Journal of the Academy of Marketing Science, vol. 47, no. 1, pp. 97-117, 2019.

[8] F. Bardhi and G.M. Echkhardt, Access-based consumption: The case of car sharing, Journal of Consumer Research, vol. 39, no. 4, pp. 881-898, 2012.

[9] S. Barnes and J. Mattsson, Understanding current and future issues in collaborative consumption: A four-stage Delphi study, Technological Forecasting and Social Change, vol, 104, no. C, pp. 200-211, 2016.

[10] A.A. Barreda, A. Bilgihan, K. Nusair, and F. Okumus, Generating brand awareness in online social networks, Computers in Human Behavior, vol. 50, no. 3312, pp. 600-609, 2015.

[11] M. Bezançon, D. Guiot and E. Le Nagard, Comment les distributeurs peuvent-ils réduire le risque perçu pour un achat d'occasion sur Internet ? Analyse exploratoire et proposition d'un nouveau cadre théorique, Colloque International de l'Association Française de Marketing, vol. 34, no. 4, pp. 3-30, 2013.

[12] J. Boase and R. Ling, Measuring mobile phone use: self- report versus log data, Journal of Computer Mediated Communication, vol. 18, no. 4, pp. 508-519, 2013.

[13] L. Bocker and T. Meelen, Sharing for people, planet or profit? Analyzing motivations for intended sharing economy participation, Environtal Innovation and Societal Transitions, vol. 23, pp. 28-39, 2017.

[14] R. Botsman and R. Rogers, What's Mine Is Yours. The Rise of Collaborative Consumption, London, 2010.

[15] N. Brace, R. Kemp and R. Snelgar, SPSS for psychologists: A guide to data analysis using SPSS for windows. (2. baskı). Hampshire: Palgrave: Macmillan, 2003.

[16] A. Bryman, Social Research Methods (2nd edition). Oxford: Oxford University Press, 2004.

[17] B. Byrne, Structural Equation Modeling with AMOS: Basic Concepts, Applications and Programming (6th ed.). New York: Taylor \& Francis, 2010.

[18] M.C. Cervellon, L. Carey and T. Harms, Something old, something used: Determinants of women's purchase of vintage fashion vs second-hand fashion, International Jouran of Retai and Distribution Management, vol. 40, no. 12, pp. 956-974, 2012.

[19] C. Cheung, X. Shen, Z. Lee, and T. Chan, Promoting sales of online games through customer engagement, Electronics Commerce Research and Applications, vol. 14, no. 4, pp. 241-250, 2015

[20] C.J. Chiu, Y.H. Hu, D.C. Lin, F.Y. Chang, C.S. Chang, and C.F. Lai, The attitudes, impact, and learning needs of older adults using apps on touchscreen mobile devices: Results from a pilot study, Computers in Human Behavior, vol. 63, 189-197, 2013.

[21] J.C. Correa, W. Garzón, P. Brooker, G. Sakarkar, S.A. Carranza, L. Yunado, and A. Rincón, Evaluation of collaborative consumption of food delivery services through web mining techniques, Journal of Retailing and Consumer Services, vol. 46, pp. 45-50, 2019. 
[22] B. Cova and V. Cova, The Consumer Experience : from manipulation to compromiso, Society and Consumtpion Conference, Rouen, Frannce, 2004

[23] D. Cyr, M. Head and A. Ivanov, Design aesthetics leading to m-loyalty in mobile commerce, Information and Management, vol. 43, no. 8, pp. 950-963, 2006.

[24] A. Diamantopoulos and J.A. Siguaw, Introducing LISREL. London: Sage Publications Ltd, 2000.

[25] Deloitte. (2018) The-consumer-is-changing. Deloitte. [Online]. Available: https://www2.deloitte.com/content/ dam/insights/us/articles/4822 The-consumer-is changing/DI The-consumer-is-changing.pdf

[26] Deloitte. (2019) Made to order: The rise of mass personaliion. Deloitte. [online]. Available: https://www2.deloitte.com/content/dam/Deloitte/ch/Documents/consumer-business/ch-en consumer-businessmade-to-order-consumer-review.pdf

[27] W.B. Dodds, K.B. Monroe and D. Grewal, Effects of price, brand, and store information on buyers, Journal of Marketing Research, vol. 28, no. 3, pp. 307-319, 1991.

[28] Y.K. Dwivedi, J. Choudrie and W.P. Brinkman, Development of a survey instrument to examine consumer adoption of broadband, Industrial Management and Data Systems, vol. 106, no. 5, pp. 700-718, 2006.

[29] E.G. Edbring, M. Lehner and O. Mont, Exploring consumer attitudes to alternative models of consumption: Motivations and barriers, Journal of Cleaner Production, vol. 123, pp. 5-15, 2016.

[30] C. Ferraro, S. Sands and J. Brace-Govan, The role of fashionability in second-hand shopping motivations, Journal of Retailing and Consumer Services, vol. 32, pp. 262-268, 2016.

[31] Forbes. (2017) Personalized customer experience increases revenue and loyalty. Forbes. [Online]. Available: https://www.forbes.com/sites/shephyken/2017/10/29/personalized-customerexperience-increases-revenue-andloyalty/\#603de8934bd6

[32] C. Fornell and D.F. Larcker, Evaluating structural equation models with unobservable variables and measurement errore, Journal of Marketing Research, vol. 18, no. 1, pp. 39-50, 1981.

[33] A. Fontana and J.H. Frey, The interview: From neutral stance to political involvement, in The SAGE Handbook of Social Research Methods (P. Alasuutari, L. Bickman and J. Brannan, Eds.). Los Angeles: SAGE, 2008, pp. 695-727.

[34] L. Gao, K.A, Waechter and X. Bai, Understanding consumers' continuance intention towards mobile purchase: A theoretical framework and empirical study - A case of China, Computers in Human Behavior, vol. 53, pp. 249262, 2015.

[35] B. Halkier and I. Jensen, Methodological challenges in using practice theory in consumption research. Examples from a study on handling nutritional contestations of food consumption, Journal of Consumer Culture, vol. 11, no. 1, pp. 101-123, 2011.

[36] J.F. Hair, W.C. Black, B.J. Babin, and R.E. Anderson, Multivariate Data Analysis: A Global Perspective (7th ed.) Upper Saddle River, NJ: Pearson Education International, 2010.

[37] J.F. Hair, W.C. Black, B.J. Babin, and R.E. Anderson, R.L.Tatham, Multivariate Data Analysis. New Jersey: Prentice Hall, 2006.

[38] J.F. Hair, W.C. Black, B.J. Babin, and R.E. Anderson, Multivariate Data Analysis: A Global Perspective (7th ed.) Upper Saddle River, NJ: Pearson Education International, 2010.

[39] J. Hamari, M. Sjöklint and A. Ukkonen, The sharing economy: Why people participate in collaborative consumption, Journal of the Association for Information Science and Technology, vol. 67, no. 9, pp. 2047-2059, 2016.

[40] R. Hobbs, Understanding the influencers of second-hand apparel shopping behavior, M.S.thesis, Wilfrid Laurier University, Faculty of Arts, 2016.

[41] J.W. Hoelter, The analysis of covariance structures goodness-of-fit índices, Sociological Methods and Research, vol. 11, no. 3, pp. 325-344, 1983.

[42] J. Hwang and M. Griffiths, Share more drive less: Millennials value perception and behavioral intent in using collaborative consumption services, Journal of Consumer Marketing, vol. 34, no. 2, pp. 132-146, 2017.

[43] A.P. Kapoor and M. Vij, Technology at the dinner table: Ordering food online through mobile apps, Journal of Retailing and Consumer Services, vol. 43, pp. 342-351, 2018.

[44] J.D. Kim and Y. Hwang, A study of mobile internet user's service quality perceptions from a user's utilitarian and hedonic value tendency perspectives, Information System Frontiers, vol. 14, no. 2, pp. 1-13, 2010.

[45] Y. Kim, Y. Park and J. Choi, A study on the adoption of loT smart home service: Using value-based adoption model, Total Quality Management and Business Excellence, vol. 28, no. 9-10, pp. 1149-1165, 2017.

[46] M. Kleijnen and V.U. Amsterdam, Consumer Adoption of Wireless Gaming Services, 2014.

[47] I. Küster, N. Vila and P. Canales, How does the online service level influence consumers' purchase intentions before a transaction? A formative approach, European Journal of Management and Business Economics, vol. 25, no. 3, pp. 111-120, 2016.

[48] R. Ladwein, Les modalités de l'appropriation de l'expérience de consommation: Le cas du tourisme urbain. Sociétés, in Consommations et consommateurs (E. Rémy and I. Garabuau, Eds.). Paris, 2003, pp. 85-98

[49] J.Y. Lai and J. Wang, Exploring the impacts of perceived e-collaboration service convenience on new product development in taiwanese IC design companies, Information Technology and Management, vol. 19, no. 2, pp. 107-120, 2018.

[50] M. Laroche, J. Bergeron and G. Barbaro-Forleo, Targeting consumers who are willing to pay more for environmentally friendly products, Journal of Consumer Marketing, vol. 18, no. 6, pp. 503-520, 2001.

[51] S.H.N. Lee and P.S. Chow, Investigating consumer attitudes and intentions toward online fashion renting retailing, Journal of Retailing and Consumer Services, vol. 52, p. 101892, 2020. 
[52] N. Lemaitre and V. De Barnier, When consumers become merchants: Motivations. Experience production and prospects, Decisions Marketing, vol. 78, pp. 1-18, 2015.

[53] S.M. Lee and S.J. Lee, Consumers' initial trust toward second-hand products in the electronic market, Journal of Cumputer Information System, vol. 46, no. 2, pp. 85-98, 2015.

[54] X. Li, T. Hess, A. McNab, and Y. Yu. (2009) Culture and acceptance of global web sites: A cross-country study of the effects of national cultural values on acceptance of a personal web portal. DATA. Semantic Scholar. [Online]. Available: https://www.semanticscholar.org/paper/Culture-and-acceptance-of-global-web-sites\%3A-astudy-Li-Hess/05a3d837157a56577bd5fd72b29bde5da85834d6

[55] Y. Liang and P. Lu, Effect of occupational mobility and health status on life satisfaction of Chinese residents of different occupations: Logistic diagonal mobility models analysis of cross sectional data on eight Chinese provinces, International Journal for Equity in Health, vol, 13, no. 15, pp.13-15, 2014.

[56] S. Liao, Q. Li and D. Xu. A Bayesian network-based framework for personalization in mobile commerce applications', Communications of the Association for Information Systems, vol. 15, no. 1, pp.494-511, 2005.

[57] F. Liébana-Cabanillas and J. Lara-Rubio, Predictive and explanatory modeling regarding adoption of mobile payment systems, Technological Forecasting and Social Change, vol. 120, pp. 32-40, 2017.

[58] J. McDougall, M. Readman and P. Wilkinson, The uses of (digital) literacy, Learning, Media and Technology, vol. 43, no. 3, pp. 263-279, 2018.

[59] Michael Page. (2018) Relocating for a job. Michael Page. [Online]. Available: https://www.michaelpage.co.uk/ad vice/career-advice/growing-your-career/relocating-job

[60] S. Moeller and K. Wittkowski, The burdens of ownership: reasons for preferring renting, Managing Service Quality: An International Journal, vol. 20, no. 2, pp. 176-191, 2010.

[61] M. Möhlmann, Collaborative consumption: determinants of satisfaction and the likelihood of using a sharing economy option again, Journal of Consumer Behaviour, vol. 14, no. 3, pp. 193-207, 2015

[62] M.M. Montoya-Weiss, G.B. Voss and D. Grewal, Determinants of online channel use and overall satisfaction with a relational multichannel service provider, Journal of the Academy of Marketing Science, vol. 31, no. x, pp. 448-458, 2003.

[63] D. Morgan, Focus Groups as Qualitative Research. London, New Delhi: Sage, Thousand Oaks, 1997.

[64] D. Murillo, H. Buckland and E. Val, When the sharing economy becomes neoliberalism on steroids: Unravelling the controversies, Technological Forecasting and Societal Changes, vol. 125, no. C, pp. 66-76, 2017.

[65] F.F.H. Nah, W. Hong, L.Q. Chen, and H.H. Lee, Information search patterns in ecommerce product comparison services, in Cross-Disciplinary Models and Applications of Database Management: Advancing Approaches. (k. Siau, Ed.). Lincoln, USA: University of Nebraska, 2012.

[66] Niti Aayog. (2017) Annual report. Niti Aayong. [Online]. Available: https://niti.gov.in/sites/default/files/201904/Annual-Report-English.pdf

[67] C.L. Newman, K. Watchter and A. White, A. Bricks or clicks? Understanding consumer usage of retail mobile apps, Journal of Services Marketing, vol. 3, no. 2, pp. 211-222, 2018

[68] J.C. Nunnally, Psychometric Theory. New York: McGraw-Hill, 1978.

[69] A.B. Ozturk, K. Nusair, F. Okumus, and D. Singh, Understanding mobile hotel booking loyalty: An integration of privacy calculus theory and trust-risk framework, Information Systems Frontiers, vol. 19, no. 4, pp. 753-767, 2017.

[70] C. Padmavathy, M. Swapana and J. Paul, Online second-hand shopping motivation - conceptualization, scale development, and validation, Journal of Retailing and Consumer Services, vol. 51, pp. 19-32, 2019.

[71] J. Paundra, L. Rook, J. Dalen, and W. Ketter, Preferences for car sharing services: Effects of instrumental attributes and psychological ownership, Journal of Environmental Psychology, vol. 53, pp. 121-130, 2017.

[72] T. Pavia, Brand names and consumer inference: The effect of adding a numeric component to a brand name, in NA - Advances in Consumer Research Volume 21 (C. T. Allen and D. R. John, Eds.). Provo, UT: Association for Consumer Research, 1984, pp. 195-200.

[73] I. Peters, O. Is, Tona and A. Popovi"c, How system quality influences mobile BI use: The mediating role of engagement, International Journal of Information Management, vol. 36, no. 5, pp. 773-783, 2016.

[74] J.L. Pierce, T. Kostova and K.T. Dirks, Toward a theory of psychological ownership in organizations, Academy of Management, vol. 26, pp. 298-310, 2001.

[75] P.M. Podsakoff, S.B. MacKenzie, J.Y. Lee, and N.P. Podsakoff, Common method biases in behavioral research: a critical review of the literature and recommended remedies, Journal of Applied Psychology, vol. 88, no. 5, pp. 879-903, 2003.

[76] PwC. (2018) Sharing or pairing. Growth of the sharing economy. PwC. [Online]. Available: https://www.pwc. com/hu/en/kiadvanyok/assets/pdf/sharing-economy-en.pdf

[77] D. Roux and D. Guiot Le développement du marché de l'occasion. Caractéristiques et enjeux pour le marché du neuf. Decis, Market, vol. 24, no. 3, pp. 25-35, 2001

[78] D. Roux and D. Guiot, Une mesure des motivations envers l'achat d'occasion leurs antécédents et leurs conséquences, Market Reserarch and Application, vol. 23, no. 4, pp. 63-95, 2008.

[79] D. Roux, Les orientations envers l'achat d'occasion.le rôle du risque perçu et de l'expertise: Quelles implications pour la distribution. Decis, Market, vol. 35, no. 2, pp. 9-21, 2004

[80] S. Sacchi, I. Kriesi and M. Buchmann, Occupational mobility chains and the role of job opportunities for upward, lateral and downward mobility in Switzerland, Research in Social Stratification and Mobility, vol. 44, no. x, pp. $10-21,2016$ 
[81] G. Said, Understanding knowledge management system antecedents of performance impact: Extending the task-technology fit model with intention to share knowledge construct, Future Business Journal, vol. 1, no. 1/2, pp. $75-87,2015$

[82] J. Sihvonen and L.L.M. Turunen, As good as new-valuing fashion brands in the online second-hand markets, Journal of Product and Brand Management, .vol. 25, no. 3, pp. 285-295, 2016.

[83] G. Sinclair and J. Tinson, Psychological ownership and music streaming consumption, Journal of Business Research, vol. 71, pp. 1-9, 2017.

[84] T. Schaefers, S.J. Lawson and M. Kukar-Kinney, How the burdens of ownership promote consumer usage of access-based services. Market. Lett., vol. 27, pp. 569-577, 2016.

[85] J. Schor, Debating the Sharing Economy. Great Transition Initiative, 2014

[86] N. Shaw and K. Sergueeva, The non-monetary benefits of mobile commerce: Extending UTAUT2 with perceived value, International Journal of Information Management, vol. 45, pp. 44-55, 2019.

[87] E. Shove and M. Pantzar, Consumers, producers and practices - understanding the invention and reinvention of nordic walking, Journal of Consumer, vol. 5, no. 1, pp. 43-64, 2005.

[88] Statista. (2018a) Mobile app usage - Statistics \& facts. Statista. [Online]. Available: https://www.statista.com/ topics/1002/mobile-app-usage/

[89] Statista. (2018b) Number of mobile app downloads worldwide in 2017, 2018 and 2022. Statista. [Online]. Available: https://www.statista.com/statistics/271644/worldwidefree- and-paid-mobile-app-store-downloads/

[90] J. Stevens, Applied Multivariate Statistics for the Social Sciences, 5th ed. London: Psychology Press, 2002.

[91] J.C. Sweeney, G.N. Soutar and L.W. Johnson, The role of perceived risk in the quality-value relationship: A study in a retail environment, Journal of Retailing, vol. 75, no. 1, pp. 77-105, 1999.

[92] B.G. Tabachnick and L.S. Fidell, Using Multivariate Statistics (5th ed.). Boston: Pearson Education, 2007.

[93] D.G.Taylor and M. Levin, Predicting mobile app usage for purchasing and information sharing, International Journal of Retail and Distributon Management, vol. 42, no. 8, pp. 759-774, 2014

[94] Thredup. (2018) The 2018 resale report. Thredup. [Online]. Available: https://www.thredup.com/resale/2018

[95] E. Turban, J. Outland, D. King, J.K. Lee, T.P. Liang, and D.C. Turban, Electronic Commerce 2018: A Managerial and Social Networks Perspective. Cham, Switzerland: Springer, 2017.

[96] A. Vance, C. Elie-Dit-Cosaque and D. Straub, Examining trust in information technology artifacts: The effects of system quality and culture, Journal of Management and Information Systems, vol. 24, no. 4, pp. 73-100, 2008.

[97] I. Van de Walle, P. Hébeln and N. Siounandan, Les secondes vies des objets: les pratiques d'acquisition et de délaissement des produits de consommation, Cahier de Recherche, vol. 290, no. 1, pp. 1-88, 2012.

[98] G. vanNoort, A.M. Voorveld and A.E. van Reijmersda, Interactivity in brand web sites: cognitive, affective, and behavioral responses explained by consumers' online flow experience, Journal of Interactive Marketing, vol. 26, no. 4, pp. 223-234, 2012.

[99] V. Venkatesh, J.Y.L Thong and X. Xu, Consumer acceptance and use of information technology: Extending the unified theory of acceptance and use of technology, MIS Quarterly, vol. 36, no. 1, pp. 157-178, 2012.

[100]V. Zeithaml, L. Berry and A. Parassuraman, The behavioral consequences of service quality, Journal of Marketing, vol. 1, pp. 31-46, 1996. 


\section{Appendix A: Measurement Scale and Items}

\begin{tabular}{|c|c|c|}
\hline Items & & Sources \\
\hline CUST1 & $\begin{array}{l}\text { Online furniture service provider offers customized product which makes me feel } \\
\text { good to be connected with it. }\end{array}$ & \multirow[t]{3}{*}{ Johnson et al., 2012} \\
\hline CUST2 & $\begin{array}{l}\text { Generally, being associated with the customized furniture gives me a sense of } \\
\text { pride. }\end{array}$ & \\
\hline CUST3 & Overall, I feel good when people associate me with the customized furniture & \\
\hline SG1 & I feel I am connected to other by renting furniture online & \multirow[t]{4}{*}{ Chen (2011) } \\
\hline SG2 & I feel like I fit in other groups, when I rent furniture online & \\
\hline SG3 & I have made connections to other people as I rent furniture online & \\
\hline SG4 & I feel comfortable communicating with other people who rent furniture online & \\
\hline OM1 & I look for better jobs, even if I have to change my geographic location & \multirow[t]{4}{*}{ Cezar (2016) } \\
\hline OM2 & I change jobs frequently & \\
\hline OM3 & I have worked in multiple cities in the last 5 years & \\
\hline OM4 & Normally, I don't prefer to stay in one city for long & \\
\hline PV1 & Online Furniture Rentals are reasonably priced & \multirow{3}{*}{$\begin{array}{l}\text { Venkatesh et al. } \\
(2012)\end{array}$} \\
\hline PV2 & Online Furniture Renting is good value for the money & \\
\hline PV3 & At the current price, online furniture renting provide good value & \\
\hline CS1 & $\begin{array}{l}\text { I prefer the complementary service such as installation and de-installation while } \\
\text { renting online }\end{array}$ & \multirow[t]{4}{*}{ Pre Study } \\
\hline CS2 & Complementary services encourages me to rent online & \\
\hline CS3 & I see value in complementary service, offered by online rental platforms & \\
\hline CS4 & $\begin{array}{l}\text { I enjoy complementary services such as free installation and assembly provided } \\
\text { by renting online }\end{array}$ & \\
\hline CONV1 & I have rented furniture 'online' in the past one month & \multirow{2}{*}{$\begin{array}{l}\text { Cezar et al. (2016) } \\
\text { and Kapoor et al. } \\
(2018)\end{array}$} \\
\hline CONV2 & I intend to rent furniture in future & \\
\hline PSYOWN1 & $\begin{array}{l}\text { The money paid for renting furniture online is not worthwhile since I cannot own } \\
\text { the items. }\end{array}$ & \multirow{3}{*}{$\begin{array}{l}\text { Edbring et al. (2016) } \\
\text { and Laroche et al. } \\
\text { (2001). }\end{array}$} \\
\hline PSYOWN2 & Not able to own the furniture items I love is annoying. & \\
\hline PSYOWN3 & I want to own the furniture items I like and feel that they are mine. & \\
\hline
\end{tabular}

